\title{
Perceptions Of Select, Newly Established Nations Of The Former Soviet Union As Foreign Direct Investment Options: A Longitudinal Perspective
}

Troy A. Festervand, Middle Tennessee State University, USA

\begin{abstract}
This study replicates a 2002 study that used perceptual mapping to identify the collective and individual positions of nine, newly established nations of the former Soviet Union as foreign direct investment (FDI) options. With the continued growth of FDI globally, the purpose of the 2010 study was to determine if significant shifts had occurred in the perceived positions of the individual nations, as well as that of the "ideal" nation. FDI executives surveyed indicated that a limited number of newly established nations (e.g., Azerbaijan, Estonia, Latvia, Lithuania, and the Ukraine) are positioned most strategically to benefit from future foreign direct investments. Of the newly established nations studied, Azerbaijan appears to hold a strategically unique position. The abundance of natural resources, the nation's improving political and economic environments, and favorable business requirements all contribute significantly to this nation's perceived position. Some nations (e.g., Armenia, Belarus, Georgia, and Moldova) continue to face significant FDI obstacles.
\end{abstract}

Keywords: Foreign Direct Investment; FDI; EurAsian; risk

\section{INTRODUCTION}

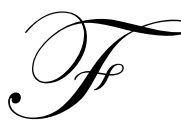

oreign Direct Investment (FDI) continues to be an integral component of the globalization of the world's economy, as well as a key aspect of every nation's economic development efforts. Virtually all nations are eager to attract FDI, as evidenced by the immense financial investments in newly developed (NDCs) or developing (LDCs) countries in recent years (Aitken et al., 1997; Jenkins, 1995; Kim, 2010; Krifa-Schneider and Matei, 2010). As is well established in economic development literature, success in attracting foreign capital is a function of a nation's resource attractiveness and the presence and availability of investment opportunities that permit or facilitate foreign direct investment (Kok and Ersoy, 2009).

Facilitating the rise in such investments have been the metamorphoses that have occurred in the social, economic, and political environments governing foreign direct investment in previously closed nations such as those of the former Soviet Union (FSU) (Agarwal, 1997; Blasi et al., 1997; Kamm, 1992; Wan 2010). These nations and socio-political environments have changed (or are in the process of changing) from essentially closed economies advocating protectionism, subsidies, and increased regulations to more market and growth-oriented positions espousing regulatory reform, market expansion, and private sector development. In turn, these changes have encouraged foreign investors to revise their view of nations considered foreign direct investment candidates. While still largely comprised of developed nations, many FDI lists now include nations (e.g., FSU nations) considered as newly developed or emerging.

Consisting of the Baltic States, as well as those now considered as South-East Europe, all of these newly established FSU nations have experienced privatization programs and related political and economic reforms designed to promote economic freedom and prosperity (Capik, 2007; Grosse and Trevino, 2005; Kornecki and 
Rhoades, 2007). Despite these reforms and major capital investments, extant evidence indicates that there has been limited improvement in the general economic performance of these nations (Bitzenis, 2004; Busse and Hefeker, 2007; Beugelsdijk, et al., 2008; Estrin and Wright, 1999; Fifka, 2008). Factors contributing to the paucity of economic growth include a decline in product demand, substantial variations in industrial output, as well as the deterioration of requisite support networks previously linked to the coordinated supply system of central planning (Anderson, 2008; Hudson, 2008).

FSU nations have received major infusions of investment capital from virtually all developed nations over the past decade (Gaddy and Ickes, 1998; Kim, 2010; Terpstra and Sarathy, 2000; Wan, 2010). While US FDI in these nations was limited during the 1980's (vis-à-vis other developing or developed countries), that changed dramatically beginning in the 1990's and continuing into the next decade (Bitzenis, 2004; Kornecki and Rhoades, 2007; PR Newswire, 2008).

However, until the integration of a free market economy, multiple factors will continue to limit the fiscal participation of US firms in FSU nations. Arguably the most significant limiting factor is the level of risk associated with a developing nation (Dichtl and Koglmayr, 1986; Grosse and Trevino 2005; Kim, 2010; Krifa-Schneider and Matei, 2010). Varying in form and magnitude, the risk associated with FSU nations often is intangible and largely based upon perception (Capik, 2007). Given the previous comments and the limited amount of empirical information that exists concerning the relative and/or perceived market position of various nations of the FSU, this research was conducted.

The purpose of the research was to identify the market position of nine newly established nations of the FSU as perceived by American business executives who participate in their company's foreign direct investment decisions. Specific objectives of the study included:

1. Empirically establish the perceived market position of nine newly established nations of the FSU

2. Develop perceived profiles of each individual newly established nation

3. Develop an aggregate profile of the ideal nation vis-à-vis the nine newly established nations studied

\section{PREVIOUS RESEARCH}

Foreign direct investment can be viewed from dual, dichotomous perspectives (i.e., investing companies/recipient countries and inward/outward investment). Relative to the former, foreign direct investment is an investment made to acquire an on-going interest (normally $10 \%$ of voting stock) in a business enterprise operating in a country other than that of the investor. Ownership of less than $10 \%$ is regarded as portfolio investment (Chowdhury and Mavrotas, 2006; World Bank, 1996).

Concerning inward/outward investment, FDI can be divided into "Greenfield" investments, also called "mortar and brick" investments, as well as mergers and acquisitions, which entail the acquisition of an existing interest rather than new investment. As such, countries can host FDI projects in their own country, as well as participate in FDI projects in other countries. A country's inward FDI position is made up of the hosted FDI projects, while outward FDI represents those investment projects owned abroad (Wan, 2010). Figure 1 presents an overview of FDI and the effects of such on both investor and recipient nations (Peng, 2011). 


\begin{tabular}{|c|c|c|}
\hline \multirow{5}{*}{ 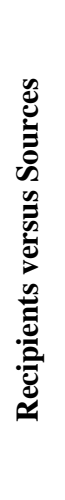 } & \multicolumn{2}{|c|}{ Host (recipient) countries } \\
\hline & $\begin{array}{ll} & \text { Cell } 1 \\
\text { - } & \text { Capital inflow } \\
\text { - } & \text { Technology } \\
\text { - } & \text { Management } \\
\text { - } & \text { Job creation }\end{array}$ & $\begin{array}{ll} & \text { Cell } 2 \\
\text { - } & \text { Loss of sovereignty } \\
\text { - } & \text { Competition } \\
\text { - } & \text { Capital outflow }\end{array}$ \\
\hline & \multicolumn{2}{|c|}{ Home (source) countries } \\
\hline & $\begin{array}{ll} & \\
\text { - } & \text { Earnings } \\
\text { - } & \text { Exports } \\
\text { - } & \text { Learning from abroad }\end{array}$ & $\begin{array}{l}\text { - } \\
\text { - } \quad \text { Jobital outflow } \\
\text { Jobs }\end{array}$ \\
\hline & Benefits & Costs \\
\hline
\end{tabular}

Figure 1: Effects of FDI

Extant literature suggests that multinational enterprises invest in foreign countries for a variety of reasons. For example, several studies have determined that investors seek to take advantage of location strengths, create a competitive advantage, or sustain the competitive advantage that they were able to create in their domestic markets (Cho and Moon, 1998; Clark, 1996; Earle and Estrin, 1996; Ensign, 1993; Estrin and Meyer, 1998; Hill and Jones, 2000; Hitt, 1996; Krifa-Schneider and Matei, 2010; Kahai and Simmons, 2005; Vance, et al., 1993). The literature also suggests that certain negative outcomes (i.e., see cells 2 \& 4) are associated with FDI (Meyer, 2004). While the benefits of FDI generally are regarded as outweighing the shortcomings, all nations must consider both perspectives prior to the FDI decision.

\section{NEWLY ESTABLISHED NATIONS OF THE FSU}

For decades, FDI was perceived as a threat to communism and national sovereignty. As a result, government policy and legislation were devised to severely restrict foreign investments, particularly from the United States. To some extent, this legacy remains intact. Hungary, for example, generally considered the most advanced post-communist country, with a successful economy and a fully functioning democracy, required almost twenty years to achieve the level needed to sustain a properly functioning market economy (Jones, 2000; Taylor, 2000).

Like Hungary, nations of the FSU suffer from decades of controlled economies. For example, despite purported long-term market controlled goals, in the short-term, the political leadership of Belarus remains quite hostile toward private business. Foreign direct investment in Belarus has been extremely slow and limited as a result of the lethargy of these privatization efforts (Filatotchev et al., 1999a and 1999b).

Another challenge has been the (in)stability of the institutional infrastructure in emerging countries that have put democratic institutions in place (Michalopoulos and Drebentsov, 1997; Michalopoulos and Tarr, 1997). For example, conflict in the Balkans, social unrest in Pakistan, tensions between Greece and Turkey, political assassinations and resignations of democratically elected governments are constant reminders of the fragility of new democracies (Buck, et al., 1999; Earle and Estrin, 1996).

To implement market economies, emerging countries may impose hardships on a population accustomed to the welfare state. In turn, this reliance leads to a rise in the popularity of communist and socialist political parties that threaten new democratic and market-oriented institutions. The prospect that these nations can at any time fall back into political and economic instability can negatively affect the perceptions that foreign investors have about these countries (Filatotchev, et al., 1999c).

However, the fall of the Berlin Wall in 1989, and the subsequent disintegration of the Soviet Union, marked a turning point in the role that multinational enterprises and national governments play in facilitating the creation of a sustainable and balanced economy. In several of the newly established nations of the FSU, the 1990's 
brought new government legislation that codified changes in public policies toward free enterprise and foreign investments (Beudegesdik, et al., 2008; Brock, 2005; Jones, 2000; Kornecki and Rhoades, 2007; McCrary, 2000).

For example, several East European governments, particularly Poland, the Czech Republic, Hungary, and Bulgaria, were some of the first such nations to enact competition laws and bilateral investment treaties aimed at encouraging foreign investments. The success of these countries (and others) in their efforts to develop marketoriented economies contributed mightily to their inclusion into the EU (Orton, 2000). More recently, the Baltic States of Estonia, Latvia, and Lithuania (now members of the EU) also have proven to be desirable FDI destinations (Bitzenis, 2004; Demekas, et al., 2007; Fifka, 2008).

Despite the progress that has been made in political and economic reform, a number of challenges continue to limit the flow of foreign investments into emerging nations. As Dunning (1993) suggested, the most important of these challenges are the political systems, values, and ideologies that most emerging nations inherited from their ancestral centralized economies. Many of these obstacles to the continued development of market-oriented economies, thus a nation's ability to attract foreign capital, remain intact (Buck, et al., 1999; Grosse and Trevino, 2005; Ramcharran, 2000).

US firms historically have chosen to invest in Europe and Japan (Terpstra and Sarathy, 2000; United Nations, 1992). This practice changed somewhat during the 1990's as US emphasis shifted to developing nations, most notably China and Brazil. While investment in these countries could be justified by the scope of the market opportunity alone, generally absent from this new investment mix were the emerging nations of the FSU (Wright, et al., 2000). While various reasons may be posited as to why US firms have taken a more cautious approach to foreign direct investment in the emerging nations of the FSU, national risk perceptions remain a viable explanation (Arcelus, Ivanova, and Srinivasan, 1996; Dutta and Roy, 2011; Kok and Ersoy, 2009; Linz, 1997).

For example, in a global study of risk, Romania, a prominent and representative member of the newly emerging nations of the FSU received an overall risk composite score of 50 (1-90, where lower scores represent higher risk). In contrast, China received a score of 69, while Switzerland received the highest overall composite risk score (94) (Erb, Campbell, and Viskanta, 1996). A decade later after the enactment of numerous reforms designed to Romania's FDI climate, Romania's score was 57 compared to China's 76 and Switzerland's 97 (Nordal, 2010); Euromoney, 2006).

Three different types of risk often are associated with a nation as a firm considers making a direct investment in that country. These risk types include the political and economic environment, domestic conditions, and economic relations (Dichtl and Koglmayr, 1986). Christiansen and Ogutcu (2002) noted that investors are influenced by the profitability or financial risk of a project, the easy with which operations can be integrated into global strategies, and the overall quality of the host's country's enabling business environment. Regardless of risk/opportunity form, executives charged with the responsibility for making the FDI decision must achieve "a more thorough understanding of the likelihood of various problems and opportunities in a country" (Kotabe and Helson, 1998). This understanding, while informed, is based upon the perception(s) of that nation, region, or market. These perceptions form what is commonly known as "market position or location."

In marketing terminology, the product's "location" is its position in the mind of a consumer. In this instance, the consumer is the foreign direct investor who is concerned with how a product (i.e., a given nation and its "bundle of attributes") is perceived. More specifically, for foreign direct investment purposes, position refers to the investor's perception of a nation vis-à-vis a competing nation as an investment option.

\section{POSITIONING: CONCEPT AND APPLICATION}

The positioning concept received its first application over thirty years ago. Since that time, it has enjoyed myriad applications ranging from consumer products, to political campaigns, to job placement. According to Ries and Trout (1981), positioning should not be confused with strategy, even though the two are inextricably related. 
Positioning is defined formally as the act of defining the product's image and value offer so that the segment's customers understand and appreciate what the product stands for in relation to its competitors (Green, 1975; Scanlon, 1994). Stated in more pragmatic terms, for a product, business, or investment option to establish an appropriate, desirable position in the marketplace, it must demonstrate to its potential stakeholders how it differs from competing options. In so doing, the host entity (i.e., each emerging nation) is attempting to establish a competitive advantage. Gilmore (2002), Young (2004), and Capik (2007), in a discussion of national promotion, specifically proposed the use of multiple promotional tools to more advantageously communicate the strengths of a particular nation and/or area within that nation.

Using the framework of research conducted almost a decade ago, the purpose of this research was to reestablishing the position of nine nations of the FSU as FDI options. Any shifts in the perceived position of these nations may speak to the effectiveness of infrastructure changes, political redirection, or promotional activities undertaken to secure inward investments. Likewise, information gleaned from this longitudinal study may offer some insight as to how and why US foreign direct investors have made their investment decisions with regard to these nations, as well as contribute to future FDI investment decisions and research.

\section{METHODOLOGY}

The data for the original research were obtained via a mail survey of a randomly selected sample of 500 executives chosen from the membership of the Industrial Development Research Council (IDRC 2000/2001). Data for the 2010 version of the study utilized the membership of CoreNet Global. Like the IRDC (which no longer functions), CoreNet Global members include representatives from manufacturing, banking, public and private development organizations, utilities, communication, and government agencies, only representatives of domestic, for-profit organizations were included in this study. CoreNet Global did not sponsor or endorse this project.

A self-administered questionnaire, the same as in the original study, was used except this version was administered electronically. The questionnaire obtained measures that identified the respondents' familiarity with each of nine newly established nations of the former Soviet Union (FSU), the perceived position of each nation, as well as specific nation-related attributes.

Each respondent was asked to indicate how familiar (s)he was with each of the nine newly established nations of the former Soviet Union studied. Familiarity was measured using bipolar adjectives, either familiar or unfamiliar. Familiarity with a nation indicated that a respondent possessed some knowledge of a nation as a foreign direct investment option. Unfamiliarity with a nation indicated that a respondent possessed little knowledge of a nation as a foreign direct investment option. The operational definitions of familiarity/unfamiliarity were provided in the instructions preceding measurement.

A common method for quantifying the position of an entity (i.e., a nation) vis-à-vis competing entities (i.e., nations), is through the technique of Multidimensional Scaling (MDS) (Green, 1975). This procedure converts ratings of perceived similarities to a geometric representation of several positions relative to one another. In turn, the perceptual map created is based upon multiple dimensions, representing the salient "top-of-mind" attributes the respondents associated with the nine newly established nations studied. By measuring the preference concerning available options, the "ideal" option also can be portrayed on a perceptual map created from perceived similarities. To allow development of the perceptual map, respondents again were asked to rate each of the nine newly established nations with respect to similarity on a five-point Likert scale $(1=$ Very Dissimilar to $5=$ Very Similar $)$. Respondents then indicated which nation they preferred.

A total of 72 usable responses were received, for an overall response rate of $12 \%$. To detect any potential nonresponse bias, a telephone survey was conducted with 15 randomly selected nonrespondents. Nonrespondents were asked to indicate the extent of their familiarity with each of the nine nations being studied. The responses of both groups (i.e., respondents and non-respondents) were reviewed by two external judges and a priorily deemed comparable. As Table 1 indicates, respondents include a variety of professionals from organizations located in all areas of the country. Compared to the 2002 study, respondents from the eastern portion of the US are over represented, thus represent a potential source of regional bias. 
Table 1: Description Of Respondents

\begin{tabular}{|c|l|}
\hline Region & \\
\hline East & $76 \%$ \\
\hline Central & $12 \%$ \\
\hline South & $8 \%$ \\
\hline West & $4 \%$ \\
\hline FDI Experience & \\
\hline Less than 3 years & $5 \%$ \\
\hline 3-9 years & $35 \%$ \\
\hline Over 9 years & $60 \%$ \\
\hline Mype of Organization & \\
\hline Nonufacturing & $66 \%$ \\
\hline Position in Organization & $34 \%$ \\
\hline Vice President/President & \\
\hline Director/Manager & $63 \%$ \\
\hline
\end{tabular}

\section{FAMILIARITY WITH SELECT NATIONS OF THE FSU}

Compared to the 2002 study, the respondents' overall familiarity with the nine nations studied was significantly greater than in the original study. These results are not surprising given the Baltic States addition to the EU in 2004, the discovery and development of energy in Azerbaijan, the continued globalization of business, and specific economic development activities of each nation aimed at attracting FDI (Fifka, 2008; Jun and Singh, 1996; Kinda, 2010).

This increased familiarity again provided the perceptual basis for subsequent responses. As indicated in Table 2, respondents were most familiar with Azerbaijan and the EU nations of Estonia, Latvia, Lithuania, as well as the Ukraine. Conversely, respondents were least familiar with the southern and eastern most nations of Armenia, Belarus, Georgia, and Moldova.

Table 2: Familiarity With Select Nations Of The Fsu

\begin{tabular}{|l|c|c|}
\hline \multicolumn{1}{|c|}{ Nation } & 2010 \% Familiarity (02\%) & 2010 \% Unfamiliarity (02) \\
\hline Armenia & $57(8)$ & $43(92)$ \\
\hline Azerbaijan & $83(13)$ & $47(87)$ \\
\hline Belarus & $53(23)$ & $32(77)$ \\
\hline Estonia & $68(18)$ & $47(93)$ \\
\hline Georgia & $53(7)$ & $33(83)$ \\
\hline Latvia & $67(17)$ & $36(76)$ \\
\hline Lithuania & $64(24)$ & $42(92)$ \\
\hline Moldova & $58(8)$ & $23(83)$ \\
\hline Ukraine & $77(17)$ & $23)$ \\
\hline
\end{tabular}

\section{PERCEPTUAL MAPPING OF SELECT NATIONS OF THE FSU}

Like its 2002 predecessor (see Figure 2), the 2010 perceptual map of FSU nations that was developed exhibited three dimensions (see Figure 3). These dimensions, which are the same in both studies, are portrayed in Figures 2 and 3 as Political and Economic Stability, Natural Resources, and Business Requirements. The perceived positions of all nations studied, as well as that of the ideal nation, are identified as relative points located along and above (denoted by a solid line) or below (denoted by a dotted line) the three axes (line length denotes the extent above or below the midpoint of each axis). 
When comparing the overall results of the two studies (i.e., 2002 and 2010), it is readily apparent that a significant shift has taken place. In the current study, virtually all of the nations studied are perceived as having improved their perceived position as a FDI destination. The five nations found to be the most disadvantageously positioned in 2002 (i.e., Armenia, Azerbaijan, Belarus, Georgia, and Moldova), now appear to be perceived as viable FDI candidates when compared to their former positions, as well as other four nations, a conclusion supported by east European FDI projections for the 2005-2010 period (Country Monitor, 2006; Oxford Analytica Daily Brief, 2007; Russia and CIS Banking and Finance Weekly, 2009).

The current findings indicate that a group of nations consisting of the Baltic States (i.e., Estonia, Latvia, and Lithuania), the Ukraine, and Azerbaijan are perceived as occupying the most strategically desirable positions. Of these nations, only the Ukraine's position appears to have deteriorated since 2002, which is surprising since FDI in the Ukraine was up approximately 6\% in 2010 (Oxford Analytica Daily Brief, 2009; Statistics Weekly, 2010). Other nations (i.e., Armenia and Belarus) appear to be clustered together, as are Georgia and Moldova, but all are perceived as being somewhat less desirable FDI locations (vis-à-vis the preceding nations). Of these latter nations, Moldova, despite its proximity to the Ukraine and the more economically developed nation of Romania, appears to be something of a FDI outlier in that it is not perceived as being as desirable an FDI location as the other nations.

As might be expected with EU membership, the Baltic States, especially Estonia, occupy desirable FDI positions (Oxford Daily Brief, 2005). Estonia, widely known as the "Baltic Tiger," is a FDI favorite, as many foreign companies chose Estonia as their initial Baltic FDI destination and then expand operations to neighboring countries (Bitzenis, 2004; Oxford Daily Brief, 2002). In contrast, both Latvia and Lithuania offer somewhat less attractive FDI opportunities because of continuing political corruption and the absence of a developed banking system similar to that of Estonia (EIU Newswire, 2010; Fifka, 2008).

As noted earlier, Moldova continues to occupy the most dubious overall position with few apparent FDI strengths. Consistent with the image generally presented in the media, three nations (i.e., Armenia, Belarus, and Georgia) are perceived as "high risk" because of political and economic instability and do not expect to see FDI increases (Statistics Weekly, 2010). Perhaps the most curious position is that occupied by Belarus. This nation is viewed as having modest natural resources, but a less than accommodating business environment and a somewhat unstable political and economic environment. Given that nation's geographic position (i.e., proximity to the Ukraine, Poland, and the Baltic nations), Belarus should be a desirable candidate for foreign direct investment. However, major shortcomings in two of the three criterion areas have limited those investments.

Azerbaijan, primarily because of its energy reserves, as well as proximity to the Caspian Sea and Middle Eastern oil-producing nations, is perceived as having (or having access to) substantial natural resources. While the stability of Azerbaijan's political and economic environment has improved markedly (Ismayilova, 2011; Russia and CIS Business and Financial Newswire, 2010), concerns of Russian interference and questionable political leadership still exist. In contrast, Azerbaijan's privatization efforts, investment in infrastructure, developing of financial and banking systems, and pro-business regulations have improved the prospects of FDI greatly (Pomfret, 2011).

Respondents perceive the ideal FSU nation as possessing qualities that may be viewed as unattainable. Executives view all qualities and factors as being important, but recognize that FSU nations will require additional time and effort before these nations can come close to such ideal standards. This research did not ascertain the relative importance of each investment criteria.

While none of the newly established nations studied occupy a position close to the ideal, Estonia comes closest. In the 2002 study, this position was occupied by the Ukraine. As the current study suggests, if Azerbaijan can sustain a stable political and economic environment, it too has the opportunity to move in the direction of the ideal nation. Perhaps it is most important to again recognize that all of the nations studied have advanced their positions in the direction of the ideal nation. Such a collective movement suggests that all of the nations studied recognize the FDI opportunity that exists and the requirements associated with such. Continued efforts to further improve these positions may well further enhance the perceived position of each nation vis-a-vis competing nations and in minds of FDI officials. 


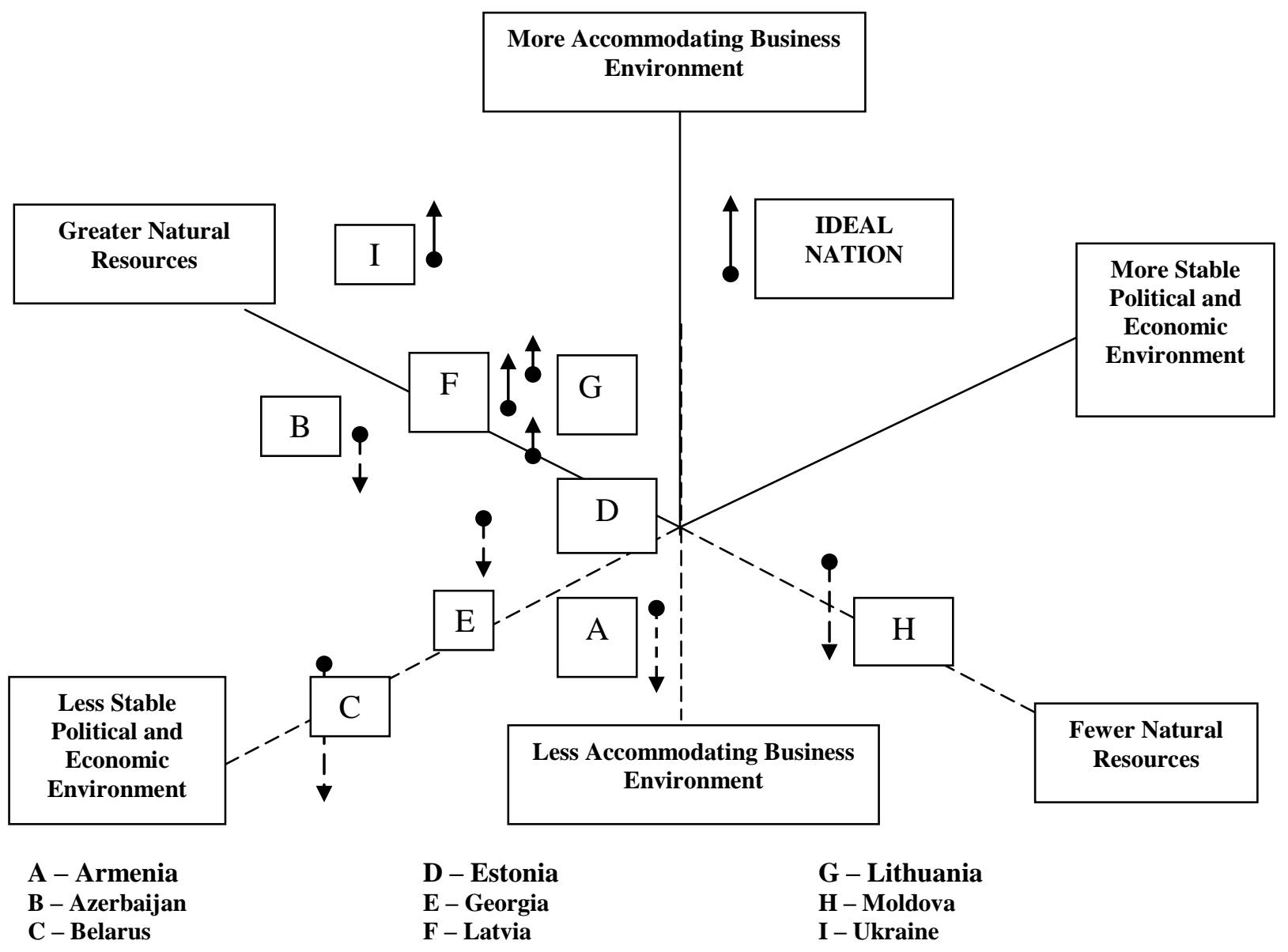

Figure 2: 2002 Perceptual Map of Select Nations of the FSU 


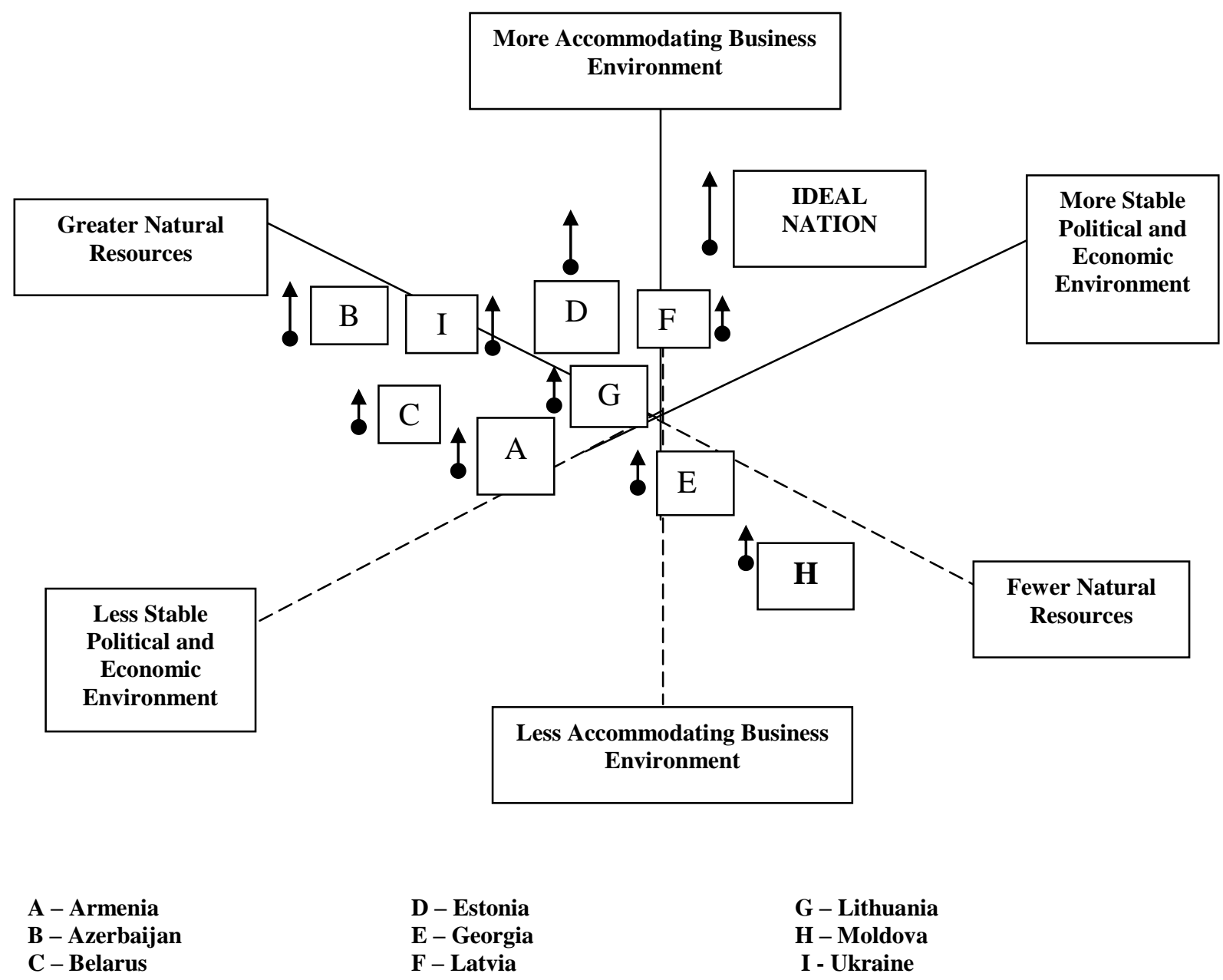

Figure 3: 2010 Perceptual Map of Select Nations of the FSU

\section{CONCLUSION}

Foreign direct investments generally are recognized as providing an opportunity for nations, governments, society, and businesses to improve economically. As such, most nations around the globe are pursuing (to some extent) direct investments by foreign governments, companies, and private investors. The pursuit of these foreign direct investments is particularly competitive among emerging and/or newly established nations, such as those of the former Soviet Union. To be successful, a nation must position itself as being more desirable than other nations, especially other FSU nations. This study was undertaken to determine if and how investment executives' perceptions of nine competing nations of the FSU had changed over the past decade.

Overall, these findings demonstrate and identify where and how nine of the newly established nations of the FSU are perceived individually and collectively. The current findings also demonstrate that the perceived position of all FSU nations studied has improved significantly over the past decade. Based upon these findings, the Baltic States, Estonia in particular, the Ukraine, and Azerbaijan are perceived as occupying the most strategically advantageous positions. In contrast, Armenia, Belarus, and Moldova have an opportunity to improve their prospects for FDI via improvements in perceived positional changes. 
The foreign direct investment challenge and opportunity for each nation lies in its desire and ability to affect meaningful and enduring change. If this commitment can be achieved, then each nation must develop an economic development program designed to capitalize on and/or ameliorate each aspect of their perceived position. Unfortunately, changes such as that required have proven problematic.

\section{AUTHOR INFORMATION}

Troy A. Festervand is Associate Dean of Graduate and Executive Education and Professor of Marketing in the Jennings A. Jones College of Business at Middle Tennessee State University (MTSU) in Murfreesboro, Tennessee. In addition to his role as Editor of the Journal of Diversity Management, his research has appeared in over a hundred scholarly journals and on the programs of many professional conferences. Professor Festervand's teaching specialties include International and Industrial Marketing.

\section{REFERENCES}

1. Agarwal, J. (1997). European Integration and German FDI: Implications for Domestic Investment and Central European Economies, National Institute Economic Review, 160: 100-111.

2. Aitken, B., Hanson, G.H. \& Harrison, A.E. (1997). Spillovers, Foreign Investment, and Export Behavior, Journal of International Economics, 43(1-2): 36.

3. Anderson, R. (2008). Baltic States on Course for Hard Landing, The Financial Times, 30 (May); 5.

4. Arcelus, F.J., Ivanova, I. \& Srinivasan, G. (1996). Comparing the Country Rankings from the Leading Assessment Measures of Competitiveness Among Nations, Advances in Competitiveness Research, 4(1): 423.

5. Beugelsdijk, S. Smeets, R. \& Zwinkels R.C.J. (2008). The Impact of Horizontal and Vertical FDI on Host's Country Economic Growth, International Business Review, 17: 452-472.

6. Bitzenis, A. (2004). Is Globalization Consistent with the Accumulation of FDI Inflows in the Balkan Countries? Regionalization for the Case of FDI Inflows in Bulgaria, European Business Review, 16 (4): 406-425.

7. Blasi, J.R., Kroumova, M. \& Kruse, D. (1997). Kremlin Capitalism: Privatizing the Russian Economy, Cornell Press, Ithaca, NY.

8. Brock, G. (2005). Post-Communist Economies. Growth in Russia During 1990s-What Role Did FDI Play? Abingdon, 17 (3): 319.

9. Buck, T., Filatotchev, I., Wright, M. \& Zhukov, V. (1999). Corporate Governance and Employee Ownership in an Economic Crisis: Enterprise Strategies in the Former Soviet Union, Journal of Comparative Economics, 27(3): 56-68.

10. Busse, M. \& Hefeker, C. (2007). Political Risk, Institutions and Foreign Direct Investment, European Journal of Political Economy, 23: 397-415.

11. Capik, P. (2007). Organizing FDI Promotion in Central-Eastern European Regions, Place Branding and Public Diplomacy, 3(2): 152-163.

12. Cho, Dong-Sung \& Moon, C. (1998). A Nation's International Competitiveness in Different Stages of Economic Development, Advances in Competitiveness Research, 6: 5-19.

13. Chowdhury, A. \& Mavrotas, G. (2006). FDI and Growth: What Causes What? The World Economy, Oxford, 29 (1): 9.

14. Clark, C. (1996). Privatization and Industrial Policy as U.S. Competitiveness Strategies: Lessons From East Asia, Advances in Competitiveness Research, 4: 101-118.

15. Demekas, D.G., Horvath, B., Ribakova, E., \& Wu, Y. (2007). Foreign Direct Investment in European Transition Economies- The Role of Policies, Journal of Comparative Economics, 35: 369-386.

16. Dhume, S. (2000). India's Awakening, Far Eastern Economic Review, January: 36-38.

17. Dichtl, E. \& Koglmayr, H.G. (1986). Country Risk Ratings, Management International Review, 26(4): 6.

18. Dunning, J.H. (1993). The Globalization of Business: The Challenge of the 1990s, London, England: Routledge.

19. Dutta, N. \& Roy, S. (2011). Foreign Direct Investment, Financial Development and Political Risks. The Journal of Developing Areas, 44(2), 303. 
20. Earle, J.S. \& Estrin, S. (1996). Employee Ownership in Transition, in R. Frydman, C.W. Gray, and A. Rapaczynski (eds.), Corporate Governance in Central Europe and Russia, 2, World Bank/CEU Press, London, 1-61.

21. Ensign, P.C. (1993). A System Theory of Foreign Direct Investment: Advantages of Being Multinational, Advances in Competitiveness Research, 1: 67-77.

22. Erb, C.B., Campbell, R. H. \& Viskanta, T.E. (1996). Expected Returns and Volatility in 135 Countries, Journal of Portfolio Management, 22(Spring): 46.

23. Estrin, S. \& Meyer, K.E. (1998). Opportunities and Tripwires for Foreign Investors in Eastern Europe, Thunderbird International Business Review, 40(May/June): 209-234.

24. Estrin, S. and Wright, M. (1999). Corporate Governance in the Former Soviet Union: An Overview, Journal of Comparative Economics, 27(3): 44.

25. Fabry, N. \& Zeghni, S. (2002). Foreign Direct Investment in Russia: How the Investment Climate Matters, Communist and Post-Communist Studies, 39 (2): 201-219.

26. Fifka, M. (2008). The Baltics: Continuing Boom or Bursting Bubble, Business Economics, 43 (4): $23-35$.

27. Filatotchev, I., Wright, M., Buck, T. \& Dyomina, N. (1999a). Exporting and Restructuring in Privatised Firms from Russia, Ukraine and Belarus, World Economy, 22(7): 913(2).

28. Filatotchev, I., Wright, M., Buck, T. \& Zhukov, V. (1999b). Corporate Entrepreneurs and Privatised Firms in Russia, Ukraine, and Belarus, Journal of Business Venturing, 14(6): 475(1).

29. Filatotchev. I., Wright, M. \& Bleaney, M. (1999c). Privatization, Insider Control and Managerial Entrenchment in Russia, Economics of Transition, 7(2): 119.

30. Gaddy, C.G. \& Ickes, B.W. (1998). Russia's Virtual Economy, Foreign Affairs, 77(5): 75.

31. Gilmore, F. (2002). A Country-Can it be Repositioned? Spain- The Success Story of Country Branding, Brand Management, 9 (4-5): 281-293.

32. Green, P.E. (1975). Marketing Applications if MDS: Assessment and Outlook, Journal of Marketing, 39 , January: 24-31.

33. Grosse, R. \& Trevino, Len J. (2005). New Institutional Economics and FDI Location in Central and Eastern Europe, Management International Review, 45 (2): 123-145.

34. Hill, C.W.L. \& Jones, G.R. (2000). Strategic Management Theory, Boston, MA: Houghton-Mifflin Company.

35. Hitt, M.A. (1996). Problems and Potential Solutions to Strategic Competitiveness in Global Market, Advances in Competitiveness Research, 4: 4.

36. Hudson, M. (2008). Fading Baltic Miracle, The International Economy, 22 (1): 74-78.

37. International Development Research Council, IDRC 2000-2001 International Membership and Resource Directory.

38. Ismayilova, N. (2011). Economic Development Minister: Political Stability in Azerbaijan Attracts Foreign Investors. McClatchy - Tribune Business News, 24 Jan 2011.

39. Jenkins, G. (1995). Investment Funds in Cuba: An Upcoming Caribbean Tiger, Columbia Journal of World Business, 30(Spring): 42.

40. Jones, C. (2000). Hungary: Post-Communist Belle of the Ball, The Banker, (July): 29-31.

41. Jun, K. \& Singh, H. (1996). 'The Determinants of Foreign Direct Investment in Developing Counties,' Transnational Corporations, 5: 67-105.

42. Kahai, S. K. \& Simmons, W. (2005). The Impact of Globalization on Income Inequity, Global Business and Economics Review, Vol. 1, No. 1.

43. $\quad$ Kamm, T. (1992). Latin Links, The Wall Street Journal, (September 24): R6.

44. Kim, Haksoon. (2010). Political Stability and Foreign Direct Investment, International Journal of Economics and Finance, 2 (3): 59-71.

45. Kinda, T. (2010). Investment climate and FDI in Developing Countries: Firm-Level Evidence, World Development, 38 (4): 498-513.

46. Kok, R. \& Ersoy, B. (2009). Analyses of FDI Determinants in Developing Countries, International Journal of Social Economics, 36: 105-123.

47. Kornecki, L. \& Rhoades, Dawna (2007). How FDI Facilitates the Globalization Process and Stimulates Economic Growth in CEE, Journal of International Business Research, 6(1): 113-126.

48. Kotabe, M. \& Helsen, K. (1998). Global Marketing Management, New York, NY: John Wiley \& Sons, Inc. 
49. Krifa-Schneider,H., and Matei, I. (2010). Business Climate, Political Risk and FDI in Developing Countries: Evidence from Panel Data, International Journal of Economics and Finance, 2(5): 54-65.

50. Linz, S.L. (1997). Russian Firms in Transition: Champions, Challengers and Chaff, Comparative Economic Studies, 39(2): 56-71.

51. McCrary, E.S. (2000). Turkey Rises to the EU Challenge, Global Finance, (June): 49-58.

52. Meyer, K. (2004).Perspectives on Multinational Enterprises in Emerging Economies, Journal of International Business Studies, 35, 259-276.

53. Michalopoulos, C. \& Drebentsov, V. (1997). Observations on State Trading in the Russian Economy, PostSoviet Geography and Economics, 38(5): 38.

54. Michalopoulos, C. \& Tarr, D. (1997). The Economics of Customs Unions in the Commonwealth of Independent States, Post-Soviet Geography and Economics, 38(3): 58-72.

55. Nordal, K.B. (2010). Country Risk, Country Risk Indices and Valuation of FDI: A Real Options Approach, Emerging Markets Review, 2:1997-217.

56. Orton, C.W. (2000). Eastern Europe Meets West, World Trade, (April): 76-80.

57. $\quad$ Peng, Mike W. (2011). Global Business. $2^{\text {nd }}$ Edition, South-Western, 194.

58. Pomfret, R. (2011). Exploiting Energy and Mineral Resources in Central Asia, Azerbaijan and Mongolia, Comparative Economic Studies, 53(1), 5.

59. Ramcharran, H. (2000). Foreign Direct Investments in Central and Eastern Europe: An Analysis of Regulatory and Country Risk Factors, American Business Review, (June): 1-8.

60. Ries, A. \& Trout, J. (1981). Positioning: The Battle for Your Mind, New York, NY: McGraw-Hill Book Company.

61. Scanlon, Jay R. (1994). Site Selection and Design for the Growth Industries, Industrial Development, (March/April): 26-29.

62. Taylor, C.T. (2000). The Impact of Host Country Government Policy on US Multinational Investment Decisions, The World Economy, (May): 635-647.

63. Terpstra, Vern \& Sarathy, Ravi (2000). International Marketing, Forth Worth, TX: Dryden Press.

64. United Nations (1992). World Economy Survey, The Economist, (September): 17.

65. Vance, C.M., Zhuplev, A., Paik, Y., \& Stage, H.D. (1993). U.S. New Business Ventures in Russia: The Host Country Workforce as a Vital Information Source for Planning and Sustaining Competitive Advantage, Advances in Competitiveness Research, 1(1): 18-28.

66. Wan, X. (2010). A Literature Review on the Relationship between Foreign Direct Investment and Economic Growth, International Business Research, 3(1): 52-56.

67. Wright, M., Buck, T. \& Filatotchev, I. (2000). Bank and Investment Fund Monitoring of Privatized Firms in Russia, Economics of Transition, Journal of Development Studies, 37(December): 44.

68. Young, C. (2004). From Place Promotion to Sophisticated Place Marketing Under Post-Socialism: The Case of CzechInvest, European Spatial Research and Policy, 11 (2): 71-84.

69. (1996).World Bank, World Debt Tables: External Finance for Developing Countries, Washington, DC.

70. (2002). Eastern Europe: Region Well Placed to Attract FDI, Oxford Analytica Daily Brief Service.

71. (2002). Estonia: Falling FDI Could Threaten External Balance, Oxford Analytica Daily Brief Service.

72. (2005). Central-Eastern Europe: FDI Surges Post-Accession, Oxford Analytica Daily Brief Service.

73. (2006). Eastern Europe: 2005-10, Country Monitor, 14 (14): 7.

74. (2006). Global Risk Indices, Euromoney.

75. (2007). Balkans/CIS: Russian FDI Inflow Belies Its Potential, Oxford Analytica Daily Brief Service.

76. (2009). CIS and the Baltic; Foreign Direct Investment in Lithuania Grows 20\% in H1, Russia \& CIS Banking \& Finance Weekly.

77. (2009). FDI Flows to the Emergers: Down But Not Out, Emerging Markets Weekly.

78. (2009). Ukraine: Prospects for Inward FDI Worsen, Oxford Analytica Daily Brief Service.

79. (2010). Direct Foreign Investment in Azerbaijan Dips 4\% in H1, Interfax: Russia \& CIS Business and Financial Newswire.

80. (2010) Finances; Foreign Investment in Ukraine in January-September 2010, Russia \& CIS Statistics Weekly.

81. (2010). Latvia: Country Outlook, EIU ViewsWire. 